\title{
Weathering and biodegradation of hydrothermal petroleum in the north rift of Guaymas Basin, Gulf of California
}

\section{Bernd R.T. Simoneit ${ }^{1}$, Daniel R. Oros ${ }^{2}$, Roald N. Leif ${ }^{3}$, and Patricia M. Medeiros ${ }^{4, \star}$}

${ }^{1}$ Department of Chemistry, College of Science, Oregon State University, Corvallis, OR 97331, U.S.A.

${ }^{2} 72$ Marina Lakes Drive, Richmond, CA 94804, U.S.A.

${ }^{3}$ Lawrence Livermore National Laboratory, Livermore, CA 94550, U.S.A.

${ }^{4}$ Department of Marine Sciences, University of Georgia, Athens, GA 30602, U.S.A.

*medeiros@uga.edu

\begin{abstract}
The Guaymas Basin, Gulf of California, is an actively spreading ocean basin, part of the system of spreading axes and transform faults extending from the East Pacific Rise to the San Andreas fault. Upward migration of hydrothermal petroleum in the basin rifts occurs by both bulk transport and high temperature/pressure aqueous and supercritical gaseous (e.g. $\mathrm{CO}_{2}, \mathrm{CH}_{4}$ ) fluid phases into the seabed sediments. The resulting mounds are laden with the youngest hydrothermal petroleum known to date. The north rift hydrothermal system has been dormant for 3000 years, and organic geochemical analyses of sediment samples collected by both piston and push corers and by dredging operations from various cruises to the Gulf of California show that the organic matter is composed primarily of autochthonous lipids from marine biota, overprinted by hydrothermal petroleum. The chemical composition of this petroleum indicates severe biodegradation for exposed samples, based on the contents of aliphatic, aromatic, steroid, and hopanoid biomarkers. Sulfurized lipids are enriched in the biodegraded oils. Both hydrothermal minerals and petroleum in the mounds of the north rift seabed have been weathered by oxidative/microbial processes.
\end{abstract}

Key words: hydrothermal petroleum; weathering; biodegradation; north rift; Guaymas Basin.

\section{RESUMEN}

La cuenca oceánica de Guaymas del Golfo de California es una cuenca de extensión activa que pertenece al sistema de ejes y fallas transformantes que se extiende desde la dorsal Este del Pacifico hasta la Falla de San Andrés. En ella se produce la migración ascendente del petróleo hidrotermal hacia los sedimentos más superficiales del fondo marino a través de las brechas de la cuenca impulsado por fases fluidas de agua a temperatura y presión altas, así como gases en condiciones supercríticas (ej. $\left.\mathrm{CO}_{2}, \mathrm{CH}_{4}\right)$. Los montículos formados resultantes contienen el petróleo hidrotermal más joven que se conoce hasta el momento. El sistema hidrotermal de la brecha norte ha estado inactivo en los últimos $\sim 3,000$ años. Los análisis orgánico-geoquímicos de sedimento recogido mediante testigos manuales, de pistón y operaciones de dragado en el Golfo de California muestran que el material orgánico está compuesto principalmente de lípidos característicos de la biota marina sobrecargada con petróleo hidrotermal. Los biomarcadores alifáticos, aromáticos, esteroides $y$ hopanoides presentes en el petróleo indican una degradación severa de las muestras expuestas a los procesos de meteorización. Dicho petróleo biodegradado está enriquecido en lípidos que contienen compuestos de azufre. En resumen, los procesos oxidativos y microbianos han meteorizado tanto los minerales hidrotermales como petróleo de los montículos de las brechas del lecho marino norte.

Palabras clave: Petróleo hidrotermal; Meteorización; Biodegradación; Brecha norte; Cuenca de Guaymas.

\section{INTRODUCTION}

The discovery and exploration of submarine hydrothermal systems (Corliss et al., 1979), with their associated chemistry and chemosynthetic biota have had a great impact on the geosciences, biosciences and chemistry (Simoneit and Lonsdale, 1982; Rona, 1984; Barrett and Fox, 1988; Childress, 1988; Simoneit, 1990, 2018; Humphris et al., 1995; Bock and Goode, 1996). The sedimentary organic matter in and around such vent systems is usually marine, derived from bioproductivity of an immature Recent origin (Simoneit, 1982a). The gas/bitumen products generated by the rapid thermal alteration in high fluid flow systems (high water to rock ratio) of generally immature organic matter in such sediments is defined as hydrothermal petroleum (Simoneit, 1999).

The Guaymas Basin in the Gulf of California (a.k.a. Sea of Cortez) is a young marginal rift basin characterized by active seafloor spreading and rapid deposition of organic-rich, diatomaceous sediments from highly productive overlying waters (Calvert, 1966). The northern and southern axial troughs of Guaymas Basin are bounded by extensive systems of axial-parallel fault lines on both sides (Lonsdale, 1985; Lonsdale and Becker, 1985). Different geochemical and temperature settings form a complex hydrothermal landscape on the seafloor. Their hydrothermal reactions generate and mobilize volatile hydrocarbons that migrate to the sediment surface (Kastner, 1982; Peter et al., 1991), limiting or favoring biological oxidation and assimilation (Teske et al., 2002, 2014; Pearson et al., 2005; Biddle et al., 2012; McKay et al., 2016). This subsurface processing system and flow pathways that ultimately reach the sediment surface are evident in hydrothermal edifices and mineral deposits, venting orifices emitting hot hydrothermal fluids, and hydrothermally altered sediments (Simoneit et al., 1990; Teske et al., 2016; Núñez-Useche et al., 2018). 
The initial exploration of Guaymas Basin started in the north rift, but after heat flow surveying it centered on the active south rift, where the hydrothermal sediments, mounds and chimneys form a complex hydrothermal landscape on the seafloor (Lonsdale, 1985; Lonsdale and Becker, 1985). Subsequently, the Deep Sea Drilling Project (DSDP) carried out coring on Leg 64 in the Guaymas Basin area. Hydrothermal petroleum was encountered at depth in both rifts and extensively in seabed mounds of the south rift. No data has been reported for the weathered mounds of the north rift. The aim of this study is to characterize the hydrothermal petroleum on a seabed mound and shallow sediment cores from the north rift of Guaymas Basin. It provides an overview of the organic biomarker compositions, diagenetic transformations, biodegradation, weathering/oxidation effects, and the dominant contributing biogenic sources of the extractable bitumen. Furthermore, this report provides comparative analytical results to those from the southern, active rift of the basin.

\section{GEOLOGICAL SETTING}

Guaymas Basin is an actively spreading ocean basin, which is part of the system of spreading axes and transform faults that extend from the East Pacific Rise to the San Andreas fault (Curray et al., 1982; Lonsdale, 1985). It is comprised of two grabens, the northern and southern rifts, connected by a transform fault zone (Figure 1). The process of ocean plate accretion results in high conductive heat flow (locally exceeding $1.2 \mathrm{~W} \cdot \mathrm{m}^{-2}$; Einsele et al., 1980). Organic-rich sediments of several hundred meters thickness overlie the spreading centers of Guaymas Basin and alternate with shallow intrusions of magmatic sills into the unconsolidated sediments producing organically-derived thermal alteration products dominated by $\mathrm{CH}_{4}, \mathrm{CO}_{2}$, and hydrocarbons (Simoneit and Lonsdale, 1982; Simoneit, 1985; Bazylinski et al., 1988; Gieskes et al., 1988; Whelan et al., 1988) that are released into sedimentary pore fluids and the ocean (Teske et al., 2016). The north rift had no obvious high heat flow signals and appeared hydrothermally dormant for $\sim 3000$ years (Williams et al., 1979). Sediments accumulate at a rate of more than $1 \mathrm{~m} / 1000$ years and have covered the rift floors to a depth of up to $400 \mathrm{~m}$ (Curray et al., 1982).

The organic matter of these recent hemipelagic sediments is derived primarily from planktonic and microbial detritus, which is highly sensitive to thermal stress and thus easily pyrolyzed (cracked) to petroleum-like products. The maximum of the oil generation "window" appears to migrate upward as the magmatic heat front moves up in the sedimentary column of the southern rift (Simoneit, 1984; 1985; Simoneit et al., 1984). Petroleum products have been described in samples from the north rift taken by shallow gravity coring (30G, Simoneit et al., 1979), piston coring (LaPaz cruise) (Simoneit, 1983a, 1983b), and deep coring (DSDP Leg 64 Hole 481; Curray et al., 1982). Seabed manifestations of petroleum were recovered by dredging operations (7D, Simoneit and Lonsdale, 1982), as well as samples taken with the deep submergence vehicle (DSV) Alvin (Simoneit, 1984, 1985; Simoneit and Kawka, 1987). These sample extracts from the north rift have been reanalyzed and their molecular compositions are discussed here in an overview.

\section{EXPERIMENTAL METHODS}

\section{Samples and extraction}

This study describes samples taken in the north rift of Guaymas Basin on various cruises in the Gulf of California. Core samples were obtained during a deep-tow and heat flow survey cruise (La Paz, Leg
2) by the $R / V$ Melville (Scripps Institution of Oceanography) during July-August 1980 , using a piston corer (10 $\mathrm{m}$ barrel with a $2 \mathrm{~m}$ gravity core trip weight). Three composited samples (six intervals of $2 \mathrm{~cm}$ each per sample) were analyzed from cores 9P (15 $\mathrm{m}$ total), $13 \mathrm{P}$ ( $15 \mathrm{~m}$ total) and $15 \mathrm{P}$ (13 $\mathrm{m}$ total) (Figure $1 \mathrm{~b})$. Site $9 \mathrm{P}$ is located on a large intra-rift hill and the core lithology consists of stiff, low-porosity mud, with possible pieces of hydrothermal crust. Sites 13P and 15P are located on a narrow ridge and coring recovered gas-charged, stiff mud and strong petroliferous odor. The core sections selected for composite analysis had a strong petroleum odor and comprised the following depth intervals: Core 9P (section 12.9-14.4 m), core 13P (section 10.5-12.4 $\mathrm{m})$, and core $15 \mathrm{P}$ (section 11.2-11.9 $\mathrm{m}$ ).

Additional samples were collected in the north rift with the DSV Alvin (dives 1621, along the continental margin fault, and 1623) in 1985 (Figure 1). Bulk samples (1623-B and 1623-C1) were a weathered sediment with oil saturated veins, and a weathered chimney with talus, respectively, from the base at the dormant mound to the west. Sample 1623-PC4 was a push-core into sediment on the rift floor near mounds. The manipulator-collected and push-core samples were subsampled at the surface and sealed in glass containers with dichloromethane (DCM) to preserve the volatiles and minimize biodegradation. The larger samples were subsequently extracted by sonication with addition of methanol $(\mathrm{MeOH})$ to remove water. The extracts were then washed with distilled-in-glass pure water to remove the inorganics. Aqueous layers were back-extracted with DCM. Aliquots of the organic extracts were dried under a pre-purified $\mathrm{N}_{2}$ stream at room temperature to constant mass (less than $1 \%$ total change in a 20 min period) and weighed. A selected number of organic extracts obtained from petroleum-rich samples were further separated into fractions. First, asphaltenes were precipitated overnight using hexane. Filtering and extensive hexane washing of the asphaltenes yielded the soluble $\mathrm{C}_{15}+$ compounds. These fractions were dried to constant weight as before for quantitation and analysis. The de-asphalted extracts were further separated by liquid-solid column chromatography on neutral alumina over silica or by thin layer chromatography (TLC) on silica to isolate the following fractions: saturated (F1), aromatic (F2), and polar (NSO, F3) compounds (Simoneit et al., 1981).

\section{Instrumental analysis}

The analyses of both total extracts and separated fractions were carried out by gas chromatography-mass spectrometry (GC-MS). Aliquots of the total extracts were silylated with $\mathrm{N}, \mathrm{O}$-bis(trimethylsilyl) trifluoroacetamide (BSTFA) containing $1 \%$ trimethylchlorosilane (TMCS) and pyridine (Pierce) for $3 \mathrm{~h}$ at $70^{\circ} \mathrm{C}$ prior to GC-MS analysis. A Hewlett-Packard 6890 GC coupled to a 5973 Mass Selective Detector was used with a DB-5MS (Agilent) fused silica capillary column (30 $\mathrm{m} \times 0.25 \mathrm{~mm}$ i.d., $0.25 \mu \mathrm{m}$ film thickness), and He as carrier gas. The GC was temperature programmed from $65^{\circ} \mathrm{C}(2 \mathrm{~min}$ initial time) to $300{ }^{\circ} \mathrm{C}$ at $6^{\circ} \mathrm{C} \mathrm{min} \mathrm{m}^{-1}$ (isothermal for $20 \mathrm{~min}$ final time). The MS was operated in the electron impact mode at $70 \mathrm{eV}$ ion source energy. Data were acquired and processed with a Hewlett-Packard ChemStation. Compounds were identified by GC retention index and comparison of mass spectra with those of authentic standards, literature and library data, and characterized mixtures. Unknown compounds were characterized by interpretation of the fragmentation pattern of their mass spectra. Compounds were quantified using the total ion current (TIC) peak area, and converted to compound mass using calibration curves of external standards. A procedural blank was run in sequence to sediment samples, presenting no significant background interferences. The mass spectra of the unknown and uncommon compounds are presented in the Supplementary Material (Figure SM 2). 


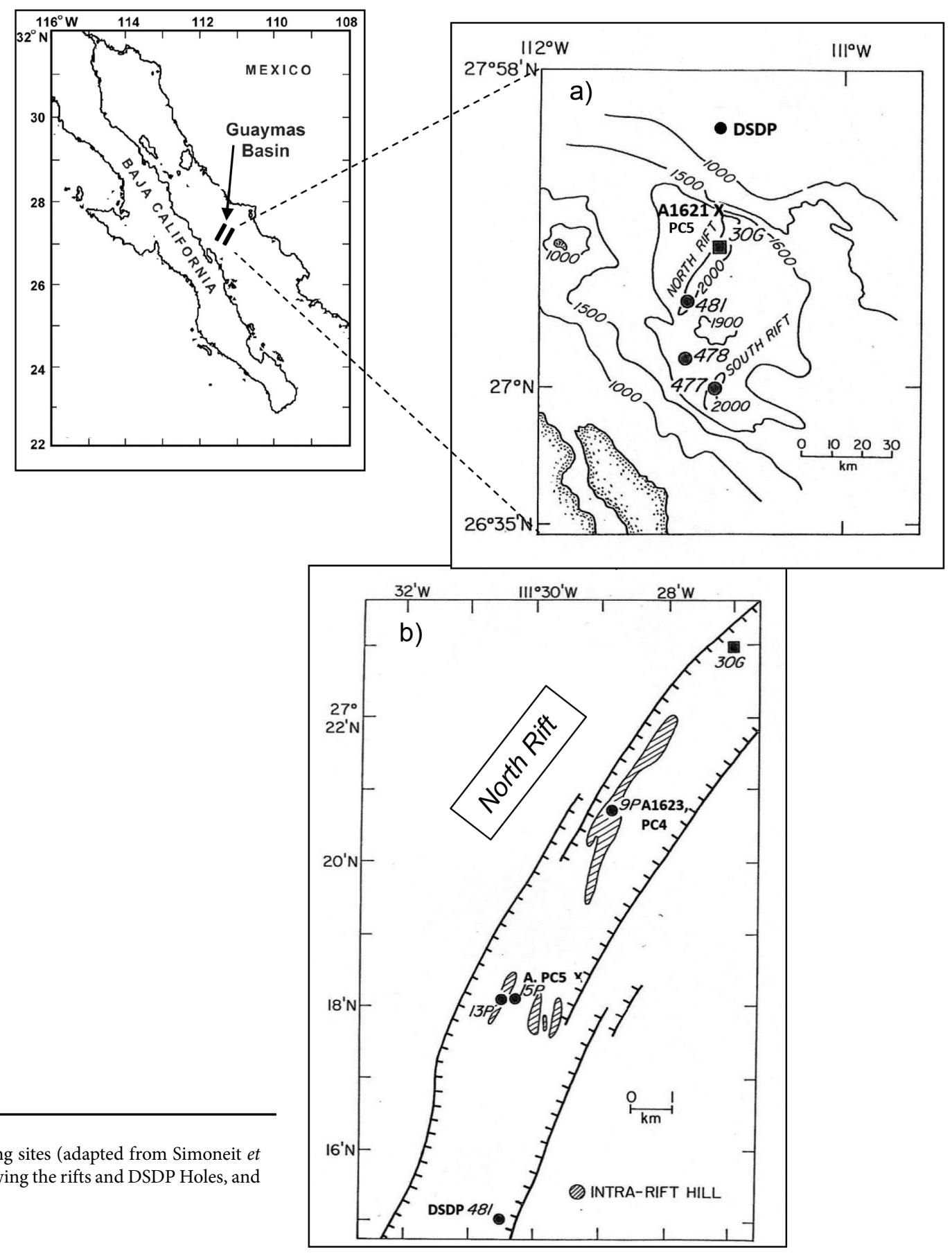

Figure 1. Location maps of sampling sites (adapted from Simoneit et al., 1983b): (a) Guaymas Basin showing the rifts and DSDP Holes, and (b) expanded view of the north rift.

\section{RESULTS AND DISCUSSION}

\section{Nature of organic matter in the Guaymas Basin hydrothermal system}

Table 1 shows the total hydrocarbon and bitumen yields of north rift samples. The first indication of diffusion of thermogenic products to the seabed from depth was found in a gravity core taken at Site 30G in the north rift (Figure 1) (Simoneit et al., 1979). The bulk of the extractable organic matter was of an autochthonous marine origin derived from planktonic/microbial detritus. The lower section of the core contained significant concentrations of gasoline range hydrocarbons
(Whelan et al., 1988). Similar migration of hydrocarbons was observed in other shallow (9P, 13P and 15P) cores or in seabed samples from this rift (Simoneit, 1983a, 1983b; Merchand et al., 1994).

DSDP Leg 64 encountered intrusives and hydrothermal alteration at depth in Holes 477, 478, and 481 (Figure 1) (Curray et al., 1982). Thermogenic hydrocarbon gas, $\mathrm{H}_{2} \mathrm{~S}$ and $\mathrm{CO}_{2}$ were identified for all sites based on composition and stable carbon isotope data (Simoneit, 1982b; Galimov and Simoneit, 1982a, 1982b; Whelan and Hunt, 1982; Simoneit and Galimov, 1984; Simoneit et al., 1988). At shallow depths, the gas data indicated a typically biogenic pattern (DSDP Sites 481 and 478, and also 30G, cf. Simoneit et al., 1979). With increasing depth, 
the $\delta^{13} \mathrm{C}$ values became heavier indicating the removal (by diffusion and/or solution) of the lighter ${ }^{12} \mathrm{CH}_{4}$ due to the thermal stress from intrusive and conductive heat sources. The $\mathrm{CH}_{4}$ at Site 477 was heaviest, reflecting the highest temperature effects, and the data for Site 481 between the sill intrusions indicated various less severe thermal effects.

The organic carbon contents of the thermally unaltered sediments in the north rift varied from 1-3 \% (Simoneit and Bode, 1982). The source of the organic matter was primarily from marine input based on its $\delta^{13} \mathrm{C}$ values (Galimov et al., 1982; Jenden et al., 1982). However, the contemporary lipids were dominated by terrigenous input superimposed on the autochthonous marine components (Rullkötter et al., 1982; Simoneit and Philp, 1982).

A sediment sample was also taken with a push core (Alvin dive 1621-PC5, Figure 1a) on the transform fault along the continental slope of the Sonoran margin. No evidence for hydrothermal activity was observed along the fault, but hydrocarbon seeps were documented there by Deep Tow survey (Lonsdale, 1985). The interstitial water of PC5 contained wet hydrocarbon gas (methane to pentane), and the solvent extract of the sediment had a low amount of mature hydrothermal petroleum superimposed on the autochthonous lipids (Simoneit et al., 1990). Thus, the hydrothermal petroleum migrated into the shallow sediments in fluids with hydrocarbon gas advecting due to regional high heat flow.

\section{North rift}

\section{Aliphatic lipid series}

Core sample 9P contained unimodal $n$-alkanes ranging from $\mathrm{C}_{13}$ to $\mathrm{C}_{33}$ with a carbon number maximum $\left(\mathrm{C}_{\max }\right)=18$ (Figure 2a). For core samples $13 \mathrm{P}$ and $15 \mathrm{P}$ the $n$-alkanes had bimodal distributions and ranged from $\mathrm{C}_{14}$ to $\mathrm{C}_{35}$ with $\mathrm{C}_{\max }$ at 24,29 and 23,29 , respectively (Figure 2c, 2d). Carbon preference index (CPI) values for these $n$ alkanes were 1.1, 1.7 and 1.2 for samples 9P, 13P and 15P, respectively (Table 1). Bimodal distributions are characteristic of dual source inputs from mainly marine algal/bacterial debris and minor terrestrial plant waxes (Simoneit, 1978; Philp, 1985), whereas for unimodal $n$-alkanes the source is marine detritus.

The lipids of the Pleistocene sediments drilled in Hole 481 had hydrocarbon distributions analogous to those described above, supporting the dual natural sources of marine productivity and terrigenous influx (Galimov et al., 1982; Rullkötter et al., 1982; Simoneit and Philp, 1982; Thomson et al., 1982). The sedimentology was assessed as typical diatomaceous ooze with mud turbidites (Curray et al., 1982).

The lipids of the samples analyzed from dive 1623 were completely overprinted with hydrothermal petroleum. The hydrocarbon fraction of one example comprised the full range of $n$-alkanes from $\mathrm{C}_{13}-\mathrm{C}_{40}$, with isoprenoids and UCM (unresolved complex mixture), whereas another was composed of only UCM with minor resolved alkylthiophenes and biomarkers as discussed below (Figure 2e, 2f).

The $n$-alkanoic acids were dominant components of cores 9P, 13P and $15 \mathrm{P}$, and ranged from $\mathrm{C}_{14}$ to $\mathrm{C}_{30}$ with $\mathrm{C}_{\max }=24$ and a strong biogenic even carbon number predominance $(\mathrm{CPI}=8-10)$ (e.g. Figure $2 \mathrm{c}, 2 \mathrm{~d}$ ). These alkanoic acids are interpreted to derive from degradation of wax esters from planktonic sources. A minor series of $n$-2-hydroxyalkanoic acids, also ranging from $\mathrm{C}_{14}$ to $\mathrm{C}_{28}$, an even carbon number predominance, but with $\mathrm{C}_{\max }=16$, supports an algal source or a bacterial alteration component (Matsumoto et al., 1984). Minor $n$-alkanols from $C_{16}$ to $\mathrm{C}_{26}$ with an even carbon number predominance and $\mathrm{C}_{\max }=16$ were present (e.g. Figure $2 \mathrm{~b}$ ), supporting a primary marine origin.

Polar lipids were reported for one sample from Hole 481 and consisted of mainly dinosterol (I, all chemical structures are shown in Appendix SM1 of the Supplementary Material), related sterols, $n$-alkanols, $n$-alkanoic acids and triterpenoids (Thomson et al., 1982). The dominant inferred lipid contributors were diatoms and bacteria, including methanogens, reflecting marine bioproductivity. The extracts of the samples from dive 1623 contained minor amounts of stigmastanol and dinosterol from dinoflagellates, with a significant amount of $\alpha$-tocopherol and hentriacontanol (Figure 3e) possibly from terrestrial plant waxes.

Lipid natural products and their oxidative and diagenetic derivatives

The natural products in the lipids preserved in the sediments, especially in samples 9P, 13P and 1623-PC4, were dinosterol (I, e.g. Figures 2, 3, SM 2a, and SM 2b), 5-dehydrodinosterol (II, Figure SM 2c), 4a,24-dimethylcholestan-3 $\beta$-ol (III, Figure SM $2 d$ ), and traces of steran-3-ones (IV, $\mathrm{R}=\mathrm{H}, \mathrm{C}_{2} \mathrm{H}_{5}$ ). These are a primary and diagenetic input from dinoflagellates (Boon et al., 1979; Robinson et al., 1984; Volkman et al., 1993, 1998). Dinosterane was not detectable in these samples, but the fate of dinosterol under hydrothermal conditions is not known. The sterols present in the shallow sediments were comprised of dominantly cholesterol $(\mathrm{V}, \mathrm{R}=\mathrm{H})$, with lesser amounts of brassicasterol (VI, Figure SM 2e) and sitosterol (V, $\left.\mathrm{R}=\mathrm{C}_{2} \mathrm{H}_{5}\right)$. Note the ethyl configuration at C-24 of sitosterol vs. clionasterol cannot be easily distinguished by GC-MS. Thus, the sterol distribution is interpreted to derive from marine microbiota (Goad, 1978), and subsequent early diagenesis altered them to steran-3-ones and sterenes (Brault and Simoneit, 1988).

a-Tocopherol (VII, Figure SM 2f) and its oxidation product 4,8,12,16-tetramethylheptadecan-4-olide (or homophytanic acid $\gamma$-lactone, VIII, Figure SM 2g) were present in sample 1623-PC4 (e.g. Figure 3e). $\alpha$-Tocopherol (vitamin E) is an antioxidant in the lipids of all higher organisms and is oxidized in the depositional environment to the lactone derivative (VIII) (Green et al., 1959).

Various diagenetic derivative compound groups were detected. Methyl ethyl maleimide (3-methyl-4-ethyl-7- $\mathrm{H}$-pyrrole-2,5-dione, IX, $\mathrm{R}=\mathrm{C}_{2} \mathrm{H}_{5}$, e.g. Figure SM 2h) and minor dimethyl maleimide

Table 1. Summary of total bitumen and hydrocarbon yields from typical samples in the north rift of Guaymas Basin.

\begin{tabular}{lccc}
\hline Samples & $\begin{array}{c}\text { Total Bitumen } \\
\text { Yield } \\
\left(\mu \mathrm{g} \cdot \mathrm{g}^{-1} \text { dry wt. }\right)\end{array}$ & $\begin{array}{c}\text { Total Hydrocarbon } \\
\text { Yield } \\
\left(\mu \mathrm{g} \cdot \mathrm{g}^{-1} \text { dry wt. }\right)\end{array}$ & CPI $^{\mathbf{1}}$ \\
(cf. Fig. 1$)$ & $1600-28000$ & $1-24$ & $1.4-3.0$ \\
\hline 30G $(-3 \mathrm{~m})$ & & & \\
DSDP Leg 64 & 1410 & 36 & 2.5 \\
481A-8-7, 0-5 & 2700 & 74 & 4.1 \\
481A-12-1, 107-109 & 1010 & 60 & 3.2 \\
481A-14-3, 50-52 & 1740 & 64 & 2.8 \\
481A-20-1, 60-62 & 560 & 26 & 3.4 \\
481A-25-cc & & & \\
Piston Cores & 2110 & 41 & 1.1 \\
9P (12.9-14.4 m) & 3040 & 17 & 1.7 \\
13P (10.5 - 12.4 m) & 5000 & 16 & 1.2 \\
15P (11.2- 11.9 m) & & & \\
DSV Alvin & 1170 & 26 & 1.1 \\
1621-PC5 & 76000 & 28000 & 1.2 \\
1623-B vein & 34200 & 680 & 1.1 \\
1623-B sediment & 27000 & 1990 & 1.1 \\
1623-C1 interior & 4800 & 72 & 0.9 \\
1623-C1 exterior & 2660 & 21 & 1.1 \\
1623-PC4 & & & \\
\hline
\end{tabular}

${ }^{1} \mathrm{CPI}$ - Carbon Preference Index summed for $n$-alkanes from $\mathrm{C}_{13}$ to $\mathrm{C}_{35}$. 

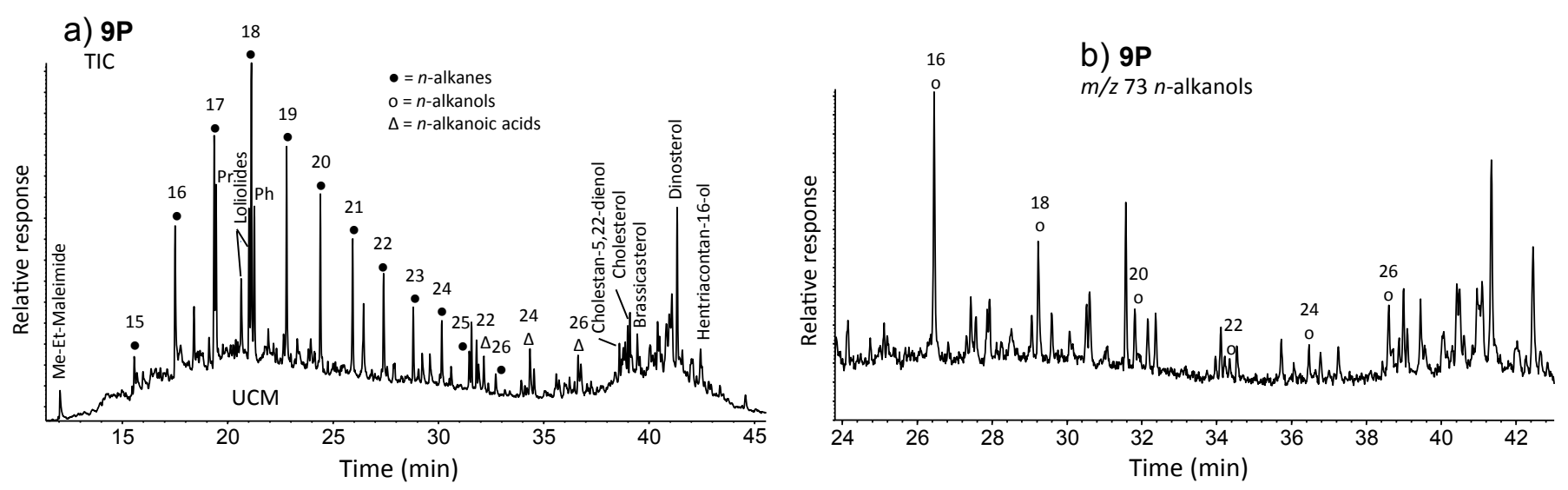

c) $13 P$
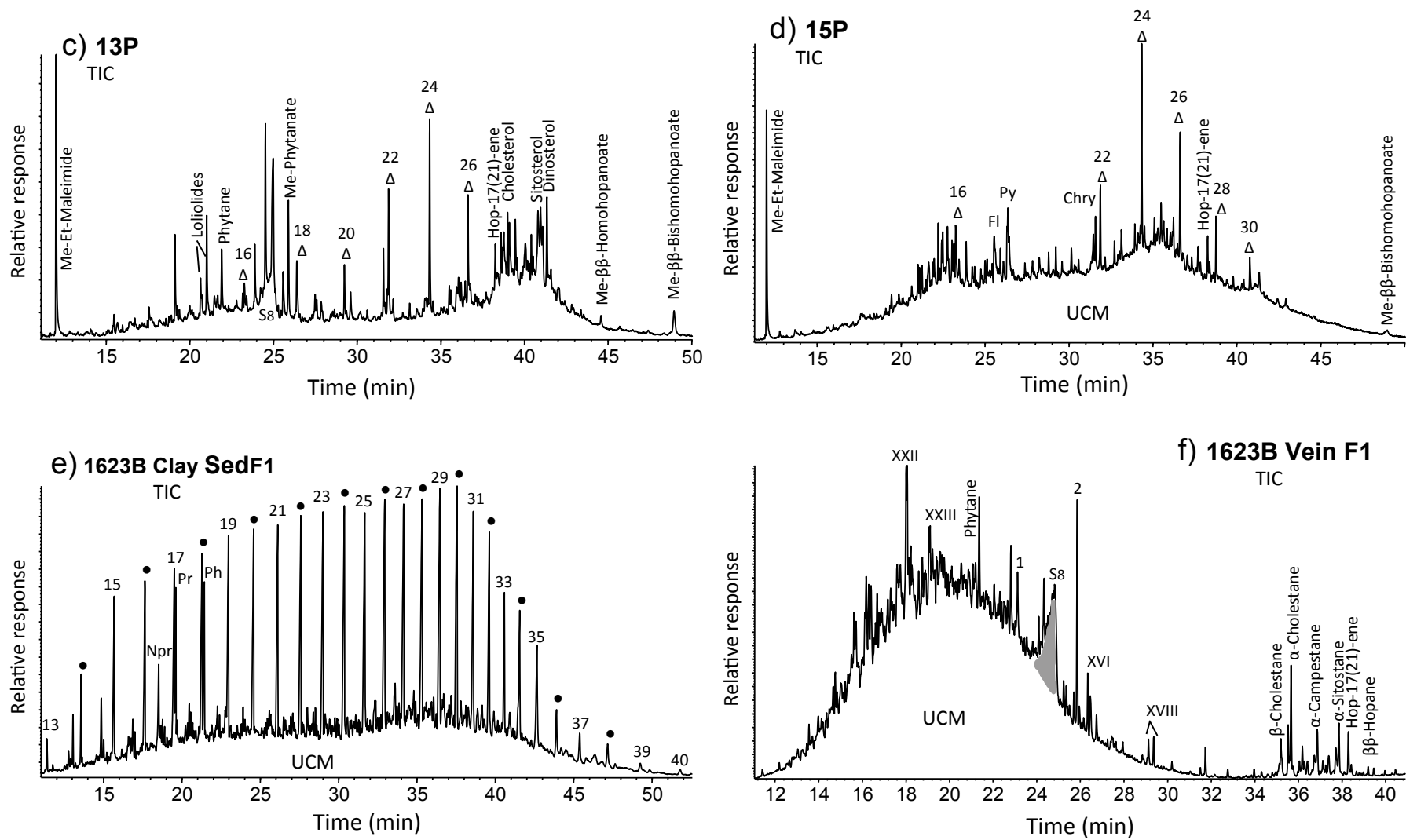

Figure 2. Annotated GC-MS data from shallow core and seabed samples: (a) Total ion current (TIC) trace for core $9 \mathrm{P}$ total extract as TMS, (b) $m / z$ 73, key ion for $n$-alkanols as TMS of core 9P total extract, (c) TIC trace for core 13P total extract as TMS, (d) TIC trace for core 15P total extract as TMS, (e) TIC trace for total hydrocarbons of sediment sample 1623B, and (f) TIC trace for total hydrocarbons of oil vein sample 1623B (Roman numerals refer to structures in Appendix SM1).

(IX, $\mathrm{R}=\mathrm{CH}_{3}$ ) were significant components in core samples 9P, 13P and $15 \mathrm{P}$ (e.g. Figure $2 \mathrm{a}, 2 \mathrm{c}, 2 \mathrm{~d})$. Their presence is interpreted as diagenetic or oxidative products from remineralization of planktonic chlorophyll (Naeher et al., 2013). The samples with high levels of maleimides also contained phytanic acid (X, Figure SM 2i) and phytone (6,10,14-trimethylpentadecan-2-one, XI, Figure SM 2j), an inferred product from phytol of chlorophyll (e.g. Ikan et al., 1973).

Significant loliolide (XII, Figure SM 2k) and iso-loliolide (XIII) were detectable in core samples $9 \mathrm{P}$ and $13 \mathrm{P}$ (Figure 2a, 2c). Their origin has been interpreted as input from carotenoid pigments undergoing rapid photochemical alteration in senescent phytoplankton detritus (Isoe et al., 1969, 1972; Klok et al., 1984; Rontani et al., 1998). The loliolide presence in sediments has also been attributed to anaerobic microbial alteration of carotenoids during diagenesis (Repeta, 1989).

Highly branched isoprenoid hydrocarbons, e.g. $\mathrm{C}_{25: 1} \mathrm{HBI}$ [i.e., 2, 6, 10, 14-tetramethyl-7-(4'-methylpentyl)pentadecane, XIV, Figure SM 21] were not detectable in these samples, but the high levels of $\mathrm{H}_{2} \mathrm{~S}$ and sulfur in these sediments resulted in diagenetic sulfurization of both isoprenoids and HBIs to series of alkylthiophenes (Sinninghe Damsté et al., 1986, 1989; Kohnen et al., 1990; Rowland et al., 1993). These were evident in extracts of the biodegraded/weathered surface sediments sampled by DSV Alvin dive 1623 (e.g. Figures 2f, 3b and, 4d). One group is comprised of the thiophene derivatives from phytol by sulfurization of phytadienes $\left(\mathrm{C}_{20} \mathrm{H}_{36} \mathrm{~S}, \mathrm{XV}\right.$-XVII, Figure SM $\left.2 \mathrm{~m}-\mathrm{SM} 2 \mathrm{o}\right)$, 
and the $7 \mathrm{R}$ and $7 \mathrm{~S}$ epimers of sulfurized $\mathrm{C}_{25: 1} \mathrm{HBIs}$ as ([2,3-dimethyl5-(2',6',10',14'-tetramethyl-7'-pentadecyl)thiophene, $\left.\mathrm{C}_{25} \mathrm{H}_{46} \mathrm{~S}\right]$, XVIII, Figure SM 2p), and 2-(1'-methylpropyl)-4-(1',5'-dimethylhexyl)5-(2',6'-dimethylheptyl)thiophene $\left(\mathrm{C}_{25} \mathrm{H}_{46} \mathrm{~S}\right.$, XIX, Figure SM 2q). The $\mathrm{C}_{25: 1} \mathrm{HBI}$ precursors are indicators for input from diatoms (e.g. Rowland and Robson, 1990; Jaffé et al., 2001). A single compound, $\mathrm{C}_{15} \mathrm{H}_{26} \mathrm{~S}$, $M W=230$, fits for 2,3-dimethyl-5-(2',6'-dimethylheptyl)thiophene (XX, Figure SM 2r), as a possible product from farnesol by sulfurization of farnesene. The other group, apparent recombination products from thermal cracking of alkylthiophene precursors, consists of compounds: 1,2-bis-methylthiophenylethane $\left(\mathrm{C}_{12} \mathrm{H}_{14} \mathrm{~S}_{2}\right.$, XXI, Figure SM 2s), 1,3-bis-methylthiophenylpropane $\left(\mathrm{C}_{13} \mathrm{H}_{16} \mathrm{~S}_{2}\right.$, XXII, Figure SM 2t), and 1,2-bis-dimethylthiophenylethane $\left(\mathrm{C}_{14} \mathrm{H}_{18} \mathrm{~S}_{2}\right.$, XXIII). This group seems to be concentrated in the biodegraded surface sediments probably due to their recalcitrance to microbial alteration. They were also found in shallow sediments of the south rift (Simoneit et al., 1992a).

\section{Biomarker hydrocarbons}

The core sections from the north rift exhibit differences in their biomarker hydrocarbon distributions indicative of overprinting by hydrothermal petroleum or variations in maturity (Kawka and Simoneit, 1987). The dominant triterpenoid compound of samples 9P, 13P and 15P was hop-17(21)-ene (XXIV, Figure SM 2u), and they had different amounts of $17 \beta(\mathrm{H}), 21 \beta(\mathrm{H})$-homohopanoic acids (XXV, Figure SM $2 \mathrm{v}$ ),
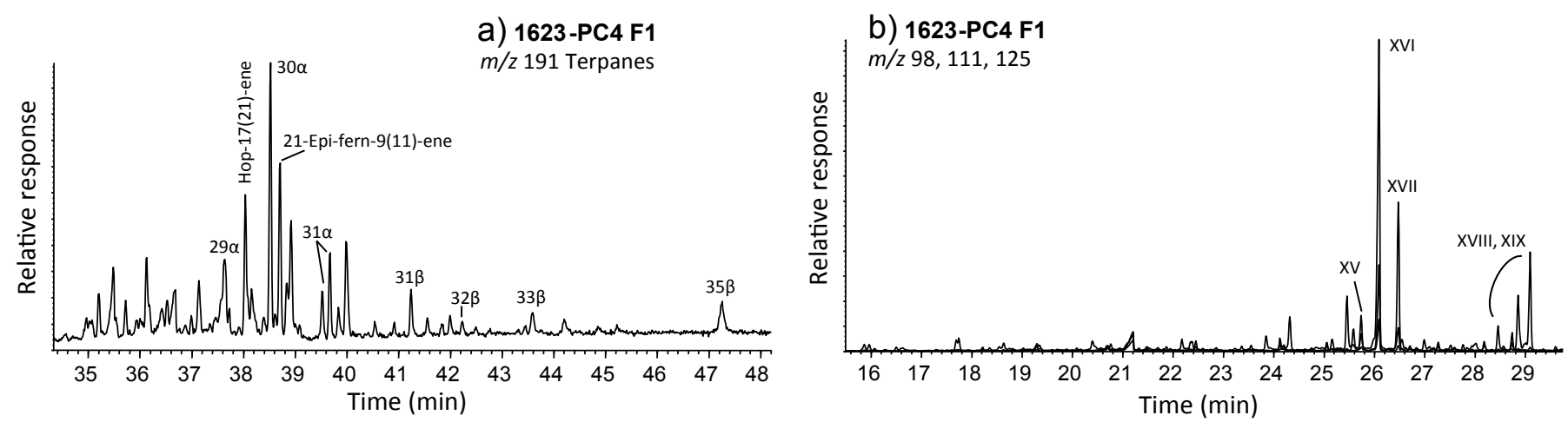

C) 1623-PC4 F2

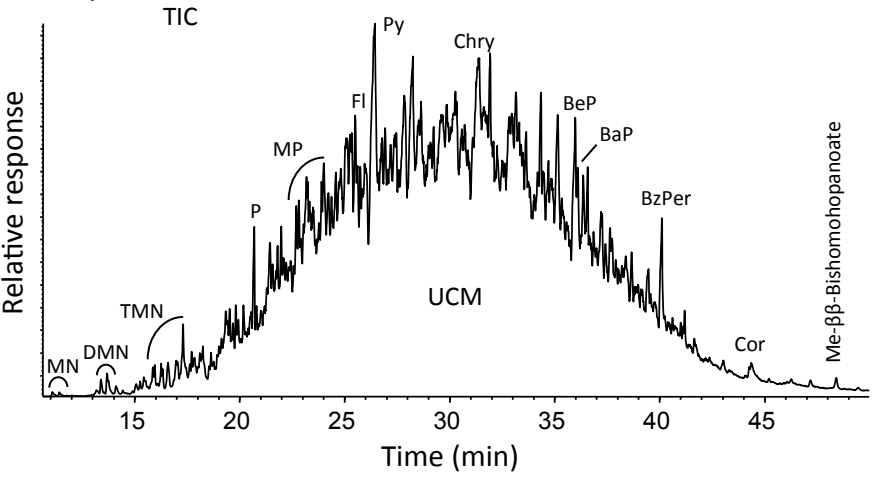

e) 1623-PC4 F3

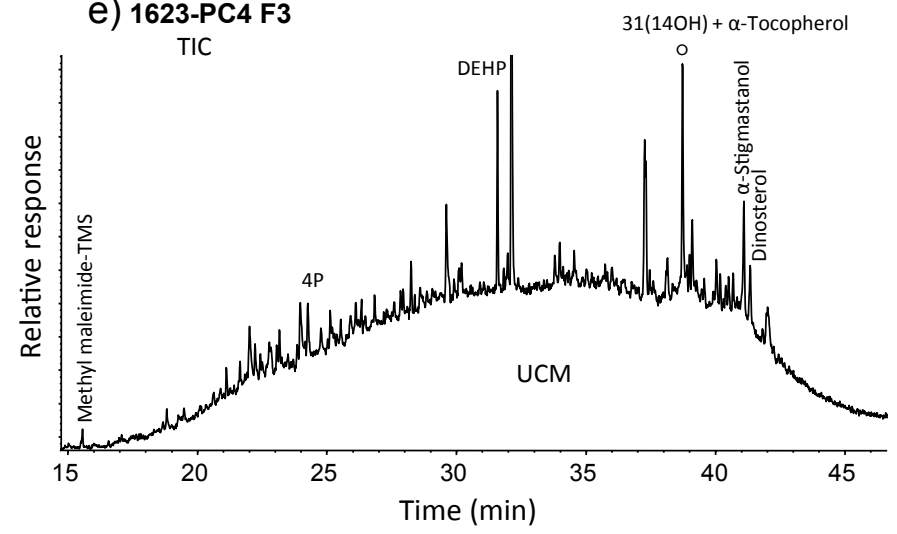

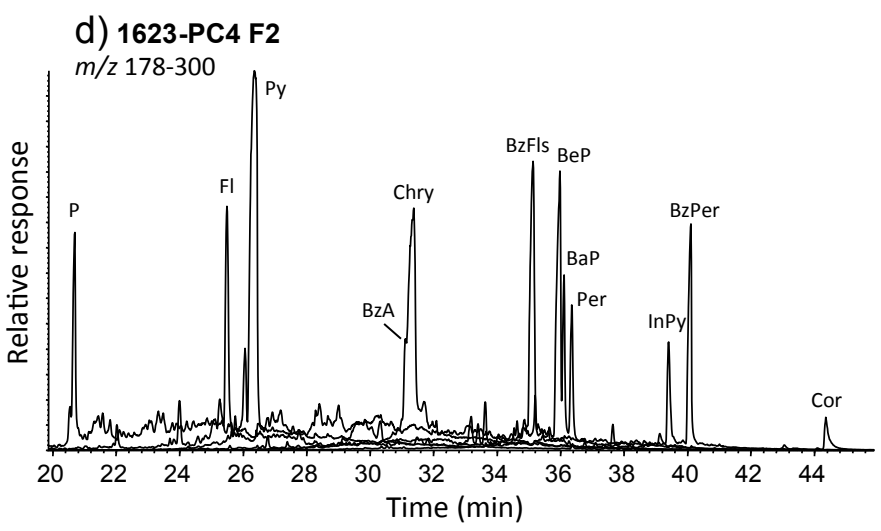

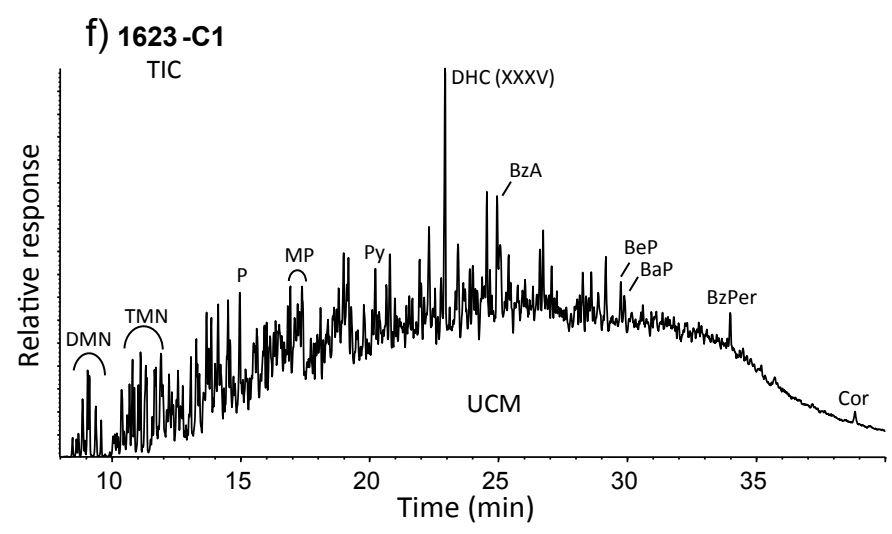

Figure 3. Annotated GC-MS data for samples from Alvin dive 1623: (a) $m / z$ 191, key ion for the triterpenoids in push core sample 1623-PC4 ( $\alpha=17 \alpha(\mathrm{H}), 21 \beta(\mathrm{H})$ and $\beta=17 \beta(\mathrm{H}), 21 \beta(\mathrm{H})$-hopane configurations), (b) $\mathrm{m} / z$ 98, 111+125, key ions for alkylthiophenes for sample 1623-PC4 (cf. Fig. 4d), (c) TIC trace of the total aromatic fraction of sample 1623-PC4 (abbreviations as in text), (d) $m / z$ 178, 202, 228, 252, 276, 300 key ions for the PAH molecular ions in the data as Figure $3 c$, (e) TIC trace of the polar fraction of sample 1623-PC4 (DEHP = diethylhexyl phthalate, 4P = butyl phthalate), and (f) TIC trace for the total extract of chimney fragment 1623-C1 (exterior). 
but only traces of $17 \beta(\mathrm{H}), 21 \beta(\mathrm{H})$-hopanes (XXVI). Sample 1623-PC4 exhibited a mixture of diagenetic and minor migrated mature hopanes (Figure 3b). The immature compounds consisted of hop-17(21)-ene, 21-epi-fern-9(11)-ene (XXVII, Figure SM 2w), and the $\beta \beta$-hopane series (XXVI) from $\mathrm{C}_{27}$ to $\mathrm{C}_{35}$ (no $\mathrm{C}_{28}$ ), with an immature $22 \mathrm{~S}$ to $22 \mathrm{R}$ epimer ratio for homohopane, $22 \mathrm{~S} /(22 \mathrm{~S}+22 \mathrm{R})=0.3$ (Peters and Moldowan, 1993). Sample 1623-B clay had mainly the fully mature $17 \alpha(\mathrm{H}), 21 \beta(\mathrm{H})$-hopanes (XXVIII) ranging from $\mathrm{C}_{27}$ to $\mathrm{C}_{35}$ (no $\mathrm{C}_{28}$ ), a minor series of $17 \beta(\mathrm{H}), 21 \alpha(\mathrm{H})$-hopanes (moretanes, XXIX) from $\mathrm{C}_{29}$ to $\mathrm{C}_{33}$, and a series of tricyclic terpanes from $\mathrm{C}_{20}$ to $\mathrm{C}_{26}$ (no $\mathrm{C}_{21}, \mathrm{XXX}$ ) (Figure $4 \mathrm{c}$ ). Both the weathered chimney sample 1623-C1 and the 1623 - $B$ vein sample had only a trace of the $\mathrm{C}_{27}$ and $\mathrm{C}_{29}-\mathrm{C}_{31} \alpha \beta$-hopanes, indicating high thermal stress that destroys biomarkers.

The steroid hydrocarbon patterns for these samples reflect their diagenetic origin from the steroid precursors to the $5 \alpha, 14 \alpha, 17 \alpha$-steranes (XXXI) and $5 \beta, 14 \alpha, 17 \alpha$-steranes (XXXII) via the ster-4-enes (XXXIII) and diasterenes (XXXIV) in the unaltered sediments (Mackenzie et al., 1982). Samples 9P and 13P were barren of steranes, diasteranes and diasterenes, but contained traces of ster-4-enes. Sample 15P had a mature sterane pattern comparable to sample 1623-B clay and samples from the south rift, with minor diasterenes and sterenes. Both samples $1623-\mathrm{B}$ vein and $1623-\mathrm{PC} 4$ had primarily the immature aaa- and $\beta a \alpha$-steranes ranging from $\mathrm{C}_{26}$ to $\mathrm{C}_{30}$ with $\mathrm{C}_{\max }=27$, and minor ster4 -enes and diasterenes (Figure $4 \mathrm{~b}$ ). The occurrence of the $\mathrm{C}_{26}$ and $\mathrm{C}_{30}$ homologues with the dominance of cholestanes (XXXI and XXXII, $\mathrm{R}=\mathrm{H}$ ) support the marine plankton origin of the precursor organic matter (Volkman, 1986). These sterane distributions are the same as reported for shallow sediments in the south rift (Simoneit et al., 1992b) and deeper samples from DSDP Hole 478 in the transform fault zone between the north and south rifts (Kawka and Simoneit, 1994). The oil saturated sample 1623-B clay had a fully mature suite of steranes and diasteranes, ranging from $C_{26}$ to $C_{29}$ with a dominance of $C_{27}>C_{28}=C_{29}$ (Figure 4a). This pattern is typical as reported for hydrothermal petroleum generated in the south rift of Guaymas Basin (e.g. Simoneit, 1990; Simoneit et al., 1992a,1992b).

\section{Polycyclic aromatic hydrocarbons}

The polycyclic aromatic hydrocarbon $(\mathrm{PAH})$ contents of the background shallow sediments were low. For samples 9P, 13P and 15P the PAH consisted mainly of the more volatile and water soluble compounds such as naphthalene $(\mathrm{N})$ to trimethylnaphthalenes (TMN), with traces of phenanthrene $(\mathrm{P})$, fluoranthene $(\mathrm{Fl})$ and pyrene $(\mathrm{Py})$. PAHs were not detectable in sample 1623-B clay, but the oxidized crust from sample $1623-\mathrm{B}$ vein had trace amounts of fluoranthene and pyrene. The weathered chimney, 1623-C1 (exterior), had a dominant amount of Diels' hydrocarbon (DHC, Simoneit et al., 1992b, XXXV, Figure SM 2x), with minor amounts of di- to pentamethylnaphthalenes on a major UCM (Figure 3f). Whereas, sample 1623-PC4 had the typical full suite of PAHs as methyl- to pentamethylnaphthalenes, phenanthrene with methyl- to pentamethylphenanthrenes, and the higher molecular weight parent PAHs from fluoranthene, pyrene, benz[a]anthracene (BzA), chrysene (Chry), benzofluoranthenes (BzFl), benzo[e]pyrene $(\mathrm{BeP})$, benzo[a]pyrene $(\mathrm{BaP})$, perylene (Per), indeno[c,d]pyrene (InPy), benzo[g,h,i]perylene (BzPer), to coronene (Cor), all on a major $\mathrm{UCM}$ (Figure 3c, 3d). This PAH distribution is as reported for the initial dredge sample (7D) and for numerous other samples recovered with DSV Alvin in the south rift (Simoneit and Lonsdale, 1982; Kawka and Simoneit, 1990; Pikovskii et al., 1996).

\section{Post-depositional alteration of hydrothermal petroleum}

During transport and deposition near the seabed, the hydrothermal petroleums can undergo water-washing and biodegradation. The number of UCM-dominated samples suggests a significant control by biodegradation (Simoneit, 1985; Simoneit and Kawka, 1987; Pearson et al., 2005). Such patterns, with little or no $n$-alkanes present, could occur by compositional fractionation through differential solubilization, as discussed previously. However, the comparison between the extracts of the interior (1170-1-2) and exterior (1170-1-3) of a hydrothermal mound fragment (Kawka and Simoneit, 1987; Simoneit and Kawka, 1987) suggested that biodegradation is important due to their striking difference. The absence of the broad distribution of $n$-alkanes found in the exterior, and the presence of identical thermally mature biomarker distributions in both, strongly supported biodegradation.

Complete removal of $n$-alkanes, as in the previous example, is an extreme form of biodegradation. An intermediate stage of biodegradation was observed for sample 1170-20-1 (red wax, Simoneit and Kawka, 1987), where the $n$-alkanes from $C_{19}$ to $C_{31}\left(C_{\max }=23\right)$ dominated the pattern. Above $\mathrm{C}_{23}$, the concentrations decreased smoothly, but disappear abruptly $<\mathrm{C}_{20}$, with only a series of isoprenoid alkanes (Pr and Ph dominant) remaining. Biodegradation, which selectively removes $n$-alkanes less than $\sim \mathrm{C}_{25}$ or the $n$-alkanes as an entire group before affecting the isoprenoids of whole crudes, could have caused such a pattern (Bailey et al., 1973; Simoneit, 1985). Thus, during biodegradation, normal (aliphatic) oils can become more polar and aromatic by both a relative increase in the non-aliphatic components due to microbial removal of $n$-alkanes and an absolute increase in the polar components as a result of this metabolism (Bailey et al., 1973; Price, 1980).

The extract compositions of the core samples from the north rift $(9 \mathrm{P}, 13 \mathrm{P}, 15 \mathrm{P})$ were not affected by biodegradation (Figure $2 \mathrm{a}-$ $2 c)$. They are varying admixtures of syngenetic lipids undergoing accelerated diagenesis due to higher heat flow, with superimposed volatile and water soluble components from migrated hydrothermal petroleum.

The hydrothermal mound area visited by DSV Alvin (dive 1623, August 1985) appeared as a weathered talus of rubble blanketed with unconsolidated, fine grained, rusty sediment. Obviously, the hydrothermal minerals had oxidized and the residual mud was enriched in metal (especially iron) oxide-hydroxides, sulfates, silicates, and carbonates. No vent biota, or remnant tube worm casts were evident, and no warm fluid discharge was found. The samples recovered were: (1) a massive chimney fragment, with intact interior sulfides and matrix saturated with oil (sample 1623-C1); (2) a large brown claystone with veins containing oil (sample 1623-B), and (3) a short push core (PC4) (Table 1).

The only unaltered hydrothermal petroleum was extracted from the bulk matrix of the brown claystone (Figures $2 \mathrm{e}$ and $4 \mathrm{a}, 4 \mathrm{c}$ ). Whereas, the oil in the veins of the same sample was a biodegraded petroleum residue of UCM, biomarkers and alkylthiophenes (Figures $2 \mathrm{f}$ and $4 \mathrm{~b}$, $4 \mathrm{~d}$ ), which may reflect heat driven emplacement of bulk biodegraded oil. The presence of alkylthiophenes indicated that this sample had experienced sulfurization reactions. The petroleum in the chimney fragment (1623-C1) is comprised of a major UCM with superimposed $\mathrm{PAH}$ and alkyl-PAH, including Diels' hydrocarbon (Figure 3f). It is a typical aromatic residue of hydrothermal petroleum pyrolysate that permeated and solidified in the chimney when active. The extracts of the push cores adjacent to the weathered mound reflect similarities to the core samples (9P, 13P, $15 \mathrm{P}$ above) in that the $n$-alkanes are mostly biodegraded, leaving a dominance of phytane and pristane (e.g. Figure 4e, 4f), with immature biomarkers (e.g. Figure 3a, 3e). The presence of alkylthiophenes and high amounts of aromatics, including PAH (Figure 3b, 3c, 3d), support the overwhelming influx of biodegraded hydrothermal petroleum into these sediments. The polar fractions of the mound samples (e.g. Figure 3e) contained residual 
a) 1623B Clay Sed F1

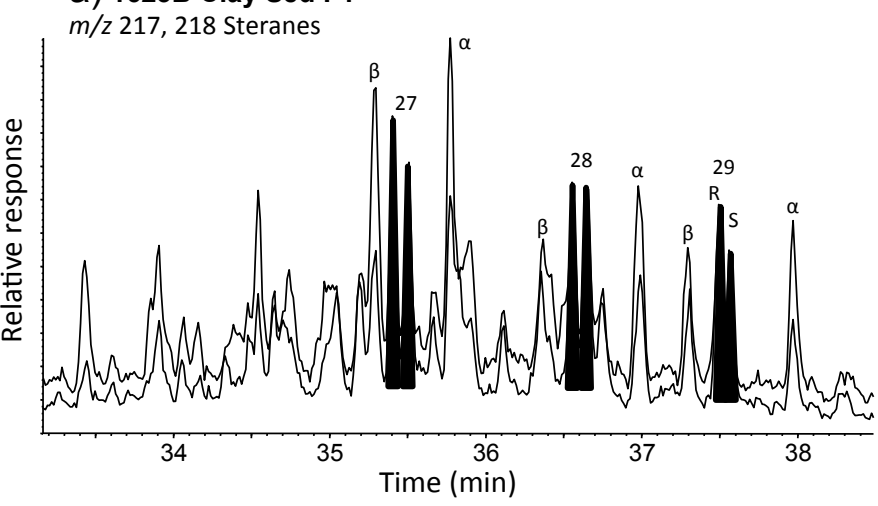

C) 1623 B Clay Sed F1

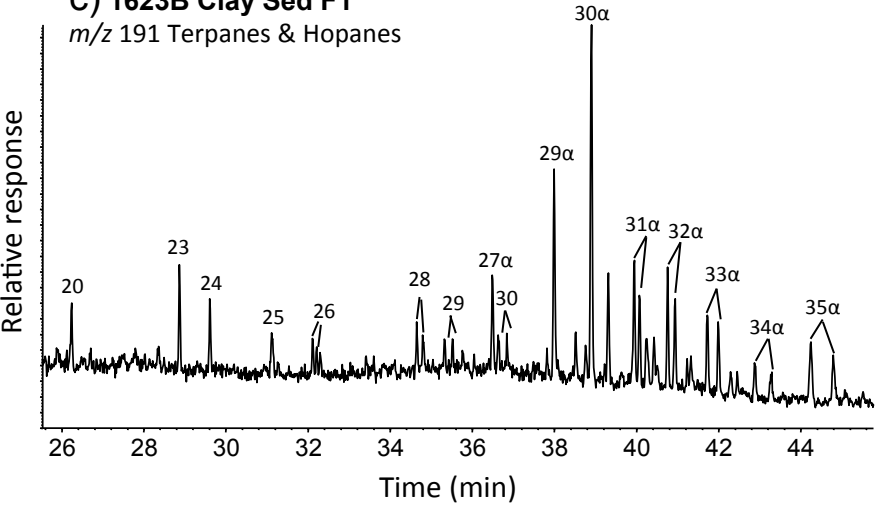

e) 1623-PC4 F1

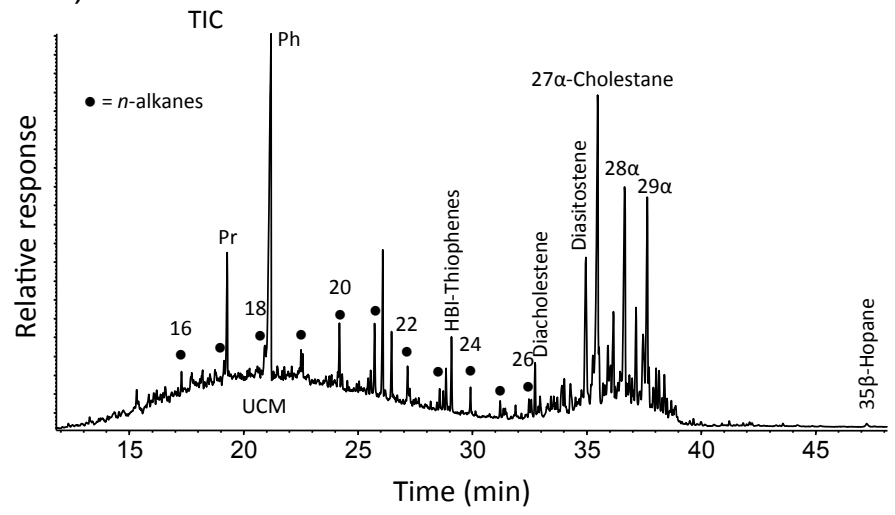

b) $1623 B$ Vein F1

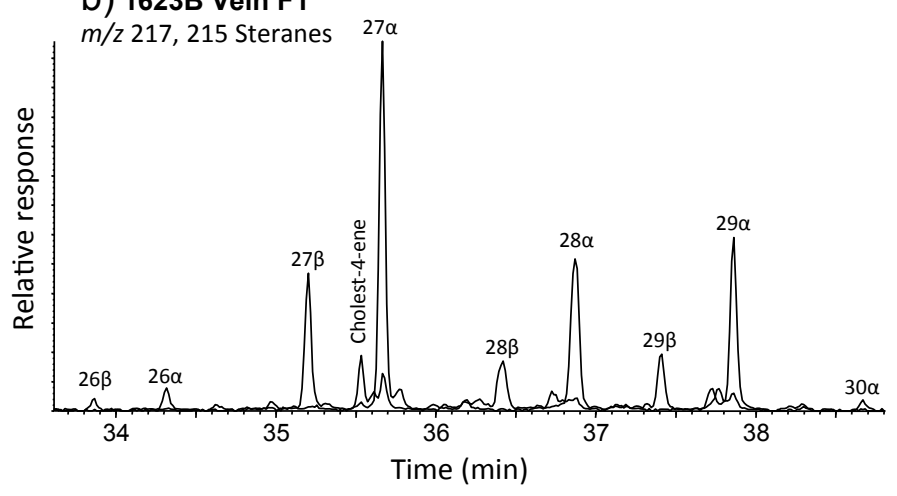

d) 1623B Vein F1
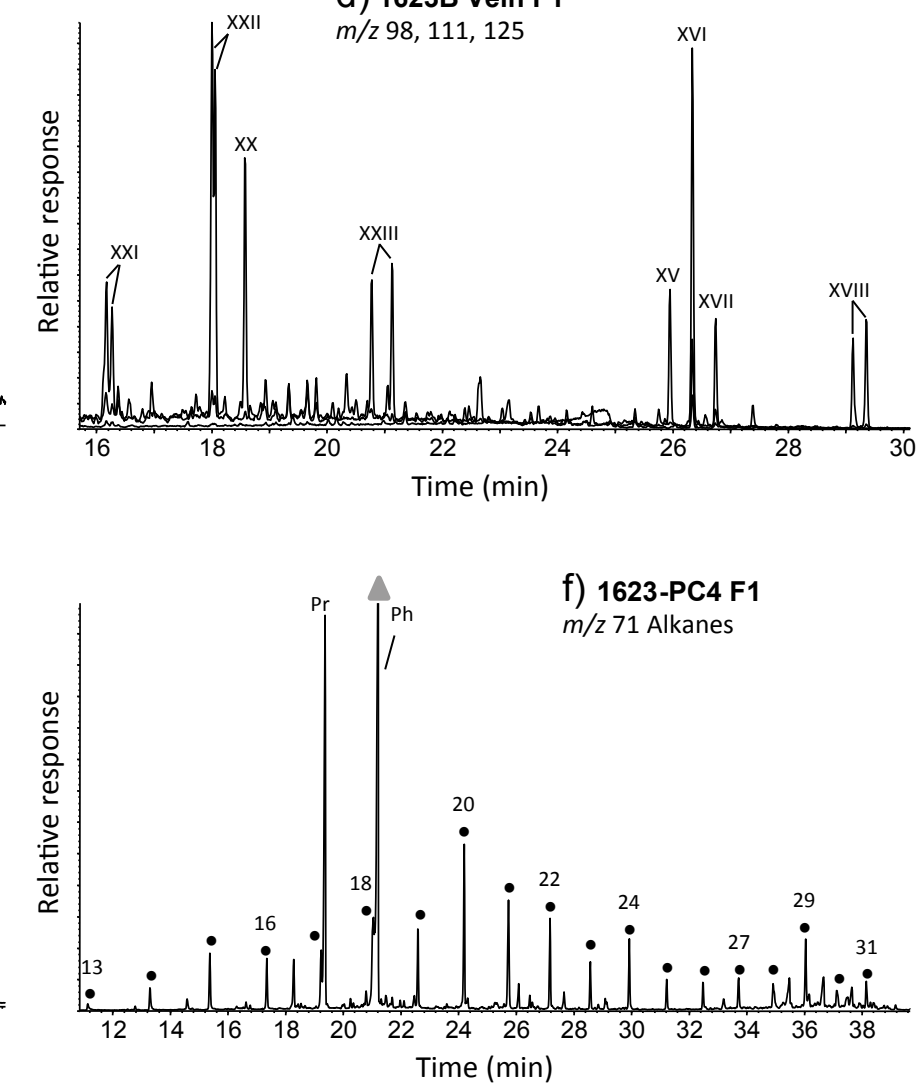

Figure 4. Annotated GC-MS data for samples from Alvin dive 1623: (a) $m / z 217+218$, key ions for steranes ( $\beta$ and $\alpha=\beta a \alpha$ and $\alpha \alpha \alpha$ R epimers at C-20, solid peaks $=\alpha \beta \beta$ isomers with 20R eluting prior to $20 \mathrm{~S}$ in F1 of clay sediment 1623B), (b) $m / z 217+215$, respective key ions for steranes and sterenes of oil vein sample 1623B, (c) $m / z$ 191, key ion trace for tricyclic terpanes $\left(\mathrm{C}_{20}-\mathrm{C}_{30}\right)$ and hopanes (all $\alpha \beta$ ) in F1 of clay sediment $1623 \mathrm{~B},(\mathrm{~d}) \mathrm{m} / z \mathrm{z}, 111+125$, key ions for alkylthiophenesin oil vein sample 1623B (Roman numerals refer to structures in Appendix SM1), (e) TIC trace for the total hydrocarbons of push core sample 1623-PC4, and (f) $\mathrm{m} / z$ 71, key ion plot showing the $n$-alkane distribution in push core sample 1623-PC4, Ph (phytane) is plotted off scale.

stanols, dinosterol, tocopherol and alkylmaleimides, reflecting the contemporary lipid input analogous as described for the core samples.

\section{South versus north rift}

The samples from the south rift exhibited a great deal of variation in the organic character of the extracts. Most of the differences amongst these samples were explainable in terms of variable mixing, differential transport, and reaction of a high-temperature hydrothermal fluid end member with the overlying sediments.
The bitumens of the core samples and push core (1623-PC4) from the north rift are distinctly different. The biomarker and total extract compositions of the three shallow samples resulted from an admixture, by hydrothermal circulation, of a low-temperature pyrolysate with the organic matter indigenous to those depths sampled. Thus, sample $15 \mathrm{P}$ exhibits the most "mature" character and 9P the most immature/bacterial character. The sediments of sample $13 \mathrm{P}$ have apparently received a smaller input of pyrolysate compared to 15P. It was observed that the sections of the cores above and below those reported (composited) 
here did not have the characteristic petroliferous odor, which is due to the presence of benzene, toluene and xylenes in the interstitial fluids (Simoneit et al., 1988). This evidence indicates migration was primarily horizontal, resulting from a sill intrusion in the vicinity, but not due to a high thermal gradient at the core location. Migration in pore fluids or diffusion is supported by the analogous observation of no obvious oil droplets visible throughout the cores (cf. Sayles and Jenkins, 1982).

The dive 1623 mound consists of hydrothermal petroleum in veins, disseminated in the semi-lithified matrix, and saturating the remnant chimney fragments. This oil has varying compositions depending on thermal history during formation and subsequent alteration during migration/deposition among the hydrothermal minerals. The oils biodegraded further where accessible as the mound weathered. The push core contains biodegraded oil in talus deposited with the minor autochthonous components from the background sedimentation in the basin. Thus, biodegradation and water-washing severely changed the oil compositions after deposition as the area visited by DSV Alvin dive 1623 weathers and oxidizes.

\section{CONCLUSIONS}

The hydrothermal petroleums from the north rift of Guaymas Basin are variable in both character and quantity, but generally fully biodegraded. Their petroleum-like hydrocarbon patterns with high PAH contents are due to pyrolysis of organic matter by overall high heat flow at depth, and localized heating due to dike and sill intrusions into the sediment, with subsequent transport to shallow depth and seabed sediments by the hydrothermal fluids and thermal gradients. The upward migration of the hydrothermal petroleum appears to have occurred by both bulk transport and a combination of high temperature/pressure aqueous and supercritical gaseous (e.g. $\left.\mathrm{CO}_{2}, \mathrm{CH}_{4}\right)$ solubilization in a multi-component fluid phase. The Guaymas north rift is currently dormant and the hydrothermal mounds with minerals and petroleum have weathered and biodegraded, resulting in a distinctively different composition compared to the south rift.

\section{ACKNOWLEDGEMENTS}

We thank the officers and crew of the research vessels Melville and Atlantis for the highly successful operations onboard. We also thank T.A.T. Aboul-Kassim for technical assistance and O.E. Kawka for valuable discussions of the data. The two reviewers are acknowledged for their constructive suggestions, which led to an improved manuscript. This research was supported by the National Science Foundation, Division of Ocean Sciences (OCE-8118897, OCE-8312036, OCE8512832, OCE-8601316, and OCE-9002366).

\section{SUPPLEMENTARY MATERIAL}

Appendix SM1 and Figure SM2 can be found at the journal web site $<$ http://rmcg.unam.mx/>, in the table of contents of this issue.

\section{REFERENCES}

Bailey, N.J.L., Jobson, A.M., Rogers, M.A., 1973, Bacterial degradation of crude oil: Comparison of field and experimental data: Chemical Geology, 11, 203-221.

Barrett, T.J., Fox, J.S., eds., 1988, Seafloor Hydrothermal Mineralization:
Canadian Mineralologist, 26, 429-888.

Bazylinski, D.A., Farrington, J.W., Jannasch, H.W., 1988, Hydrocarbons in surface sediment from a Guaymas Basin hydrothermal vent site: Organic Geochemistry, 12, 547-558.

Biddle, J.F., Cardman, Z., Mendlovitz, H., Albert, D.B., Lloyd, K.G., Boetius, A., Teske A., 2012, Anaerobic oxidation of methane at different temperature regimes in Guaymas Basin hydrothermal sediments: ISME Journal, 6, 1018-1031, https://doi.org/10.1038/ismej.2011.164.

Bock, G.R., Goode, J.A., eds., 1996, Evolution of Hydrothermal Ecosystems on Earth (and Mars?): CIBA Foundation Symposium 202, John Wiley \& Sons, Chichester, $334 \mathrm{pp}$.

Boon, J.J., Rijpstra, W.I.C., de Lange, F., de Leeuw, J.W., Yoshioka, M., Shimizu, Y. 1979, Black-Sea sterol - a molecular fossil for dinoflagellate blooms: Nature, 277, 125-127.

Brault, M., Simoneit, B.R.T., 1988, Steroid and triterpenoid distributions in Bransfield Strait sediments: Hydrothermally-enhanced diagenetic transformations: Organic Geochemistry, 13, 698-705.

Calvert, S.E., 1966, Origin of diatom-rich, varved sediments from the Gulf of California: Journal of Geology, 74, 546-565.

Childress, J.J., ed., 1988, Hydrothermal Vents. A Case Study of the Biology and Chemistry of a Deep-Sea Hydrothermal Vent of the Galapagos Rift: Deep Sea Research, 35, 1677-1849.

Corliss, J.B., Dymond, J., Gordon, L.I., Edmond, J.M., von Herzen, R.P., Ballard, R.D., Green, K., Williams, D., Bainbridge, A., Crane, K., van Andel, T.H., 1979, Submarine thermal springs on the Galapagos Rift: Science, 203, 1073-1083.

Curray, J.R., Moore, D.G., Aguayo, J.E., Aubry, M.P., Einsele, G., Fornari, D.J., Geiskes, J., Guerrero, J.C., Kastner, M., Kelts, K., Lyle, M., Matoba, Y., Molina-Cruz, A., Niemitz, J., Rueda, J., Saunders, A.D., Schrader, H., Simoneit, B.R.T., Vacquier, V., 1982, Initial Reports of the Deep Sea Drilling Project, Vol. 64, Parts I and II: Washington, D.C., U.S. Government Printing Office, 1314 pp.

Einsele, G., Geiskes, J., Curray, J., Moore, D., Aguayo, E., Aubry, M.P., Fornari, D.J., Guerrero, J.C., Kastner, M., Kelts, K., Lyle, M., Matoba, Y., MolinaCruz, A., Niemitz, J., Rueda, J., Saunders, A., Schrader, H., Simoneit, B.R.T., Vacquier, V., 1980, Intrusion of basaltic sills into highly porous sediments and resulting hydrothermal activity: Nature, 283, 441-445.

Galimov, E.M., Simoneit, B.R.T., 1982a, Geochemistry and interstitial gases in sedimentary deposits of the Gulf of California, Leg 64, in Curray, J.R., Moore, D.G., et al. (eds.), Initial Reports of the Deep Sea Drilling Project, Vol. 64: Washington, D.C., U.S. Government Printing Office, 781-788.

Galimov, E.M., Simoneit, B.R.T., 1982b, Variations in the carbon isotope compositions of $\mathrm{CH}_{4}$ and $\mathrm{CO}_{2}$ in the sedimentary sections of the Guaymas Basin (Gulf of California): Geokhimiya, 20(7), 1027-1034.

Galimov, E.M., Kodina, L.A., Bogacheva, M.P., Shirinsky, V.G., 1982. Organic geochemical studies of samples from Deep Sea Drilling Project Leg 64, Gulf of California: Sites 474, 477, 478, 479, and 481, in Curray, J.R., Moore, D.G., et al. (eds.), Initial Reports of the Deep Sea Drilling Project, Vol. 64: Washington, D.C., U.S. Government Printing Office, 819-836.

Gieskes, J.M., Simoneit, B.R.T., Brown, T., Shaw, T., Wang, Y.-C., Magenheim, A., 1988, Hydrothermal fluids and petroleum in surface sediments of Guaymas Basin, Gulf of California: A case study: Canadian Mineralogist, 26, 589-602.

Goad, L.J., 1978, The sterols of marine invertebrates: Composition, biosynthesis, and metabolites, in Scheuer, P.J. (ed.), Marine Natural Products: New York, Academic Press, 75-172.

Green, J., McHale, D., Marcinkiewicz, S., Mamalis, P., Watt, P.R., 1959, Tocopherols, Part V, Structural studies on e- and n-tocopherol: Journal of the Chemical Society (Resumend), 3362-3373.

Humphris, S.E., Zierenberg, R.A., Mullineaux, L.S., Thomson, R.E., eds., 1995, Seafloor Hydrothermal Systems, Physical, Chemical, Biological, and Geological Interactions: Washington, D.C., American Geophysical Union, Geophysical Monograph, 91, 466 pp.

Ikan, R., Baedecker, M.J., Kaplan, I.R., 1973, C $_{18}$ isoprenoid ketone in recent marine sediments: Nature, 244, 154-155.

Isoe, S., Hyeon, S.B., Sakan, T., 1969, Photooxygenation of carotenoids. I. The formation of dihydroactinidiolide and $\beta$-ionone from $\beta$-carotane: Tetrahedron Letters, 10, 279-281.

Isoe, S., Hyeon, S.B., Katsumara, S., Sakan, T., 1972, Photooxygenation 
of carotenoids. II. The absolute configuration of loliolide and dihydroactinidiolide: Tetrahedron Letters, 13, 2517-2520.

Jaffé, R., Mead, R., Hernandez, M.E., Peralba, M.C., DiGuida, O.A., 2001, Origin and transport of sedimentary organic matter in two subtropical estuaries: a comparative, biomarker-based study: Organic Geochemistry, 32, 507-526.

Jenden, P.D., Simoneit, B.R.T., Philp, R.P., 1982, Hydrothermal effects on protokerogen of unconsolidated sediments from Guaymas Basin, Gulf of California: Elemental composition, stable carbon isotope ratios, and electron spin resonance spectra, in Curray, J.R., Moore, D.G., et al. (eds.), Initial Reports of the Deep Sea Drilling Project, Vol. 64: Washington, D.C., U.S. Government Printing Office, 905-912.

Kastner, M., 1982, Evidence for two distinct hydrothermal systems in the Guaymas Basin, in Curray, J.R., Moore, D.G., et al. (eds.), Initial Reports of the Deep Sea Drilling Project, Vol. 64: Washington, DC, U.S. Government Printing Office, 1143-1158.

Kawka, O.E., Simoneit, B.R.T., 1987, Survey of hydrothermally-generated petroleums from the Guaymas Basin spreading center: Organic Geochemistry 11, 311-328.

Kawka, O.E., Simoneit, B.R.T., 1990, Polycyclic aromatic hydrocarbons in hydrothermal petroleums from the Guaymas Basin spreading center, in Simoneit, B.R.T. (ed.), Organic Matter Alteration in Hydrothermal Systems - Petroleum Generation, Migration and Biogeochemistry: Applied Geochemistry 5, 17-27.

Kawka, O.E., Simoneit, B.R.T., 1994, Hydrothermal pyrolysis of organic matter in Guaymas Basin: I. Comparison of hydrocarbon distributions in subsurface sediments and seabed petroleums: Organic Geochemistry, 22, 947-978.

Klok, J., Baas, M., Cox, H.C., de Leeuw, J.W., Rijpstra, W.I.C., Schenck, P.A., 1984, Loliolides and dihydroactinidiolide in a recent marine sediment probably indicate a major transformation pathway of carotenoids: Tetrahedron Letters, 25, 5577-5580.

Kohnen, M.E.L., Sinninghe Damsté, J.S., Kock-van Dalen, A.C., ten Haven, H.L., Rullkötter, J., de Leeuw, J.W.,1990, Origin and diagenetic transformation of $\mathrm{C}_{25}$ and $\mathrm{C}_{30}$ highly branched isoprenoid sulfur compounds: further evidence for the formation of organically bound sulfur during early diagénesis: Geochimica et Cosmochimica Acta, 54, 3053-3063.

Lonsdale, P., 1985, A transform continental margin rich in hydrocarbons, Gulf of California: American Association of Petroleum Geologists Bulletin, 69, 1160-1180

Lonsdale, P., Becker, K., 1985, Hydrothermal plumes, hot springs, and conductive heat flow in the Southern Trough of Guaymas Basin: Earth and Planetary Science Letters, 73, 211-225.

Mackenzie, A.S., Brassell, S.C., Eglinton, G., Maxwell, J.R., 1982, Chemical fossils: The geological fate of steroids: Science, 217, 491-504.

Matsumoto, G., Shioya, M., Nagashima, H., 1984, Occurrence of 2-hydroxy acids in microalgae: Phytochemistry, 23, 1421-1423.

McKay, L., Klokman, V.W., Mendlovitz, H.P., LaRowe, D.E., Hoer, D.R., Albert, D., Amend, J.P., Teske, A., 2016, Thermal and geochemical influences on microbial biogeography in the hydrothermal sediments of Guaymas Basin, Gulf of California: Environmental Microbiology Reports, 8, 150-161.

Merchand, M., Termonia, M., Caprais, J.C., Wybauw, M., 1994, Purge and trap GC-MS analysis of volatile organic compounds from the Guaymas Basin hydrothermal site (Gulf of California): Analusis, 22, 326-331.

Naeher, S., Schaeffer, P., Adam, P., Schubert, C.J., 2013, Maleimides in recent sediments - using chlorophyll degradation products for palaeoenvironmental reconstructions: Geochimica et Cosmochimica Acta, 119, 248-263.

Núñez-Useche, F., Canet, C., Liebetrau, V., Pi Puig, T., Ponciano, A.C., Alfonso P., Berndt, C., Hensen, C., Mortera-Gutierrez, C., Rodríguez-Díaz, A.A., 2018, Redox conditions and authigenic mineralization related to cold seeps in central Guaymas Basin, Gulf of California: Marine and Petroleum Geology, 95, 1-18.

Pearson, A., Seewald, J.S., Eglinton, T.I., 2005, Bacterial incorporation of relict carbon in the hydrothermal environment of Guaymas Basin: Geochimica et Cosmochimica Acta, 69, 5477-5486.

Peter, J.M., Peltonen, P., Scott, S.D., Simoneit, B.R.T., Kawka, O. E., 1991, ${ }^{14} \mathrm{C}$ ages of hydrothermal petroleum and carbonate in Guaymas Basin, Gulf of California: implications for oil generation, expulsion, and migration: Geology, 19, 253-256.

Peters, K.E., Moldowan, J.M., 1993, The Biomarker Guide: Englewood Cliffs,
Prentice Hall, 363 pp.

Philp, R.P., 1985, Fossil Fuel Biomarkers, Applications and Spectra: Amsterdam, Elsevier, $294 \mathrm{pp}$.

Pikovskii, Y.I., Chernova, T.G., Alekseeva, T.A., Kozin, I.S., 1996, New data on the composition of polycyclic aromatic hydrocarbons in sulfides and bottom sediments of the Guaymas Basin (Gulf of California): Geokhimia, 5, 455-462 (translation Geochemistry International, 34, 408-415).

Price, L.C., 1980, Crude oil degradation as an explanation of the depth rule: Chemical Geology, 28, 1030.

Repeta, D.J., 1989, Carotenoid diagenesis in recent marine sediment, II. Degradation of fucoxanthin to loliolide: Geochimica et Cosmochimica Acta, 53, 699-707.

Robinson, N., Eglinton, G., Brassell, S.C., Cranwell, P.A., 1984. Dinoflagellate origin for sedimentary $4 a$-methylsteroids and $5 a(\mathrm{H})$-stanols. Nature, $308,439-442$.

Rona, P.A., 1984. Hydrothermal mineralization at seafloor spreading centers: Earth Science Reviews, 20, 1-104.

Rontani, J.-F., Cuny, P., Grossi, V., 1998, Identification of a "pool" of lipid photoproducts in senescent phytoplanktonic cells: Organic Geochemistry, $29,1215-1225$.

Rowland, S.J., Robson, J.N., 1990. The widespread occurrence of highly branched acyclic $\mathrm{C}_{20}, \mathrm{C}_{25}$ and $\mathrm{C}_{30}$ hydrocarbons in recent sediments and biota - a review: Marine Environmental Research, 30, 191-216.

Rowland, S., Rockey, C., Al-Lihaibi, S.S., Wolff, G.A., 1993, Incorporation of sulphur into phytol derivatives during simulated early diagénesis: Organic Geochemistry, 20, 1-5.

Rullkötter, J., von der Dick, J., Welte, D.H., 1982, Organic petrography and extractable hydrocarbons of sediments from the Gulf of California, Deep Sea Drilling Project Leg 64, in Curray, J.R., Moore, D.G., et al. (eds.) Initial Reports of the Deep Sea Drilling Project, Vol. 64: Washington, D.C., U.S. Government Printing Office, 837-853.

Sayles, F.L., Jenkins, W.J., 1982, Advection of pore fluids through sediments in the equatorial east Pacific: Science, 217, 245-248.

Simoneit, B.R.T., 1978, The organic chemistry of marine sediments, in Riley, J.P., Chester, R. (eds.) Chemical Oceanography: London, Academic Press, 7, 233-311.

Simoneit, B.R.T., 1982a, The composition, sources and transport of organic matter to marine sediments - the organic geochemical approach, in Thompson, J.A.J., Jamieson, W.D. (eds.), Symposium on Marine Chemistry into the Eighties, Proceedings: Ottawa, Canada, Natural Resources Council of Canada, 82-112.

Simoneit, B.R.T., 1982b, Shipboard organic geochemistry and safety monitoring, Leg 64, Gulf of California, in Curray, J.R., Moore, D.G., et al. (eds.) Initial Reports of the Deep Sea Drilling Project, Vol. 64, Part II: Washington, D.C., U.S. Government Printing Office, 723-727.

Simoneit, B.R.T., 1983a, Organic matter maturation and petroleum genesis: Geothermal versus hydrothermal, in The Role of Heat in the Development of Energy and Mineral Resources in Northern Basin and Range Province: Davis, California, Geothermal Research Council, Special Report No. 13, 215-241.

Simoneit, B.R.T., 1983b, Effects of hydrothermal activity on sedimentary organic matter: Guaymas Basin, Gulf of California - petroleum genesis and protokerogen degradation, in Rona, P.A., Boström, K., Laubier, L., Smith Jr., K.L. (eds.), Hydrothermal Processes at Seafloor Spreading Centers: New York, NATO-ARI Series, Plenum Press, 451-471.

Simoneit, B.R.T., 1984, Hydrothermal effects on organic matter - high versus low temperature components: Organic Geochemistry, 6, 857-864.

Simoneit, B.R.T., 1985, Hydrothermal petroleum: Genesis, migration and deposition in Guaymas Basin, Gulf of California: Canadian Journal of Earth Sciences, 22, 1919-1929.

Simoneit, B.R.T., 1990, Petroleum generation, an easy and widespread process in hydrothermal systems: an overview: Applied Geochemistry, 5, 3-15.

Simoneit, B.R.T., 1999, Petroleum - hydrothermal, in Marshall, C.P., Fairbridge, R.W. (eds.), Encyclopedia of Geochemistry: Dordrecht, Kluwer Academic Publishers, 497-498.

Simoneit, B.R.T., 2018, Hydrothermal petroleum, in Wilkes, H. (ed.) Hydrocarbons, Oils and Lipids: Diversity, Origin, Chemistry and Fate: Berlin, Springer International Publishing. AG, DOI: https://doi. org/10.1007/978-3-319-54529-5_16-2. 
Simoneit, B.R.T., Bode, G.R., 1982, Appendix II, Carbon/carbonate and nitrogen analyses, Leg 64, Gulf of California, in Curray, J.R., Moore, D.G., et al. (eds.), Initial Reports of the Deep Sea Drilling Project, Vol. 64, Part II: Washington, D.C., U.S. Government Printing Office, 1303-1306.

Simoneit, B.R.T., Galimov, E.M., 1984, Geochemistry of interstitial gases in Quaternary sediments of the Gulf of California: Chemical Geology, 43, 151-166.

Simoneit, B.R.T., Kawka, O.E., 1987, Hydrothermal petroleum from diatomites in the Gulf of California, in Brooks, J., Fleet, A.J. (eds.) Marine Petroleum Source Rocks: Geological Society of London Special Publication, 26, 217-228.

Simoneit, B.R.T., Lonsdale, P.F., 1982. Hydrothermal petroleum in mineralized mounds at the seabed of Guaymas Basin. Nature, 295, 198-202.

Simoneit, B.R.T., Philp, R.P., 1982, Organic geochemistry of lipids and kerogen and the effect of basalt intrusions on unconsolidated oceanic sediments: Sites 477, 478, and 481, Guaymas Basin, Gulf of California, in Curray, J.R., Moore, D.G., et al. (eds.) Initial Reports of the Deep Sea Drilling Project, Vol. 64, Part II: Washington, D.C., U.S. Government Printing Office, 883-904.

Simoneit, B.R.T., Mazurek, M.A., Brenner, S., Crisp, P.T., Kaplan, I.R., 1979, Organic geochemistry of Recent sediments from Guaymas Basin, Gulf of California: Deep-Sea Research, 26A, 879-891.

Simoneit, B.R.T, Brenner, S., Peters, K.E., Kaplan, I.R., 1981, Thermal alteration of Cretaceous black shale by basaltic intrusions in the Eastern Atlantic, II: Effects on bitumen and kerogen: Geochimica et Cosmochimica Acta, $45,1581-1602$.

Simoneit, B.R.T., Philp, R.P., Jenden, P.D., Galimov, E.M., 1984, Organic geochemistry of Deep Sea Drilling Project sediments from the Gulf of California: - Hydrothermal effects on unconsolidated diatom ooze: Organic Geochemistry, 7, 173-205.

Simoneit, B.R.T., Kawka, O.E., Brault, M., 1988, Origin of gases and condensates in the Guaymas Basin hydrothermal system, in Schoell, M. (ed.), Origins of Methane in the Earth: Chemical Geology, 71, 169-182.

Simoneit, B.R.T., Lonsdale, P.F., Edmond, J.M., Shanks III, W.C., 1990, Deepwater hydrocarbon seeps in Guaymas Basin, Gulf of California, in Simoneit, B.R.T. (ed.), Organic Matter Alteration in Hydrothermal Systems - Petroleum Generation, Migration and Biogeochemistry: Applied Geochemistry, 5, 41-49.

Simoneit, B.R.T., Leif, R.N., Sturz, A.A., Sturdivant, A.E., Gieskes, J.M., 1992a, Geochemistry of shallow sediments in Guaymas Basin, Gulf of California: Hydrothermal gas and oil migration and effects of mineralogy: Organic Geochemistry, 18, 765-784.

Simoneit, B.R.T., Kawka, O.E., Wang, G.-M., 1992b, Biomarker maturation in contemporary hydrothermal systems, alteration of immature organic matter in zero geological time, in Moldowan, J., Philp, R.P., Albrecht, P. (eds.), Biological Markers in Sediments and Petroleum: Englewood Cliffs, NJ, Prentice Hall, 124-141.

Sinninghe Damsté, J.S., ten Haven, H.L., de Leeuw, J.W., Schenck, P.A., 1986, Organic geochemical studies of a Messinian evaporitic basin, northern Apennines (Italy) - II. Isoprenoid and $n$-alkyl thiophenes and thiolanes: Organic Geochemistry, 10, 791-805.
Sinninghe Damsté, J.S., van Koet, E.R., Kock-van Dalen, A.C., de Leeuw, J.W., Schenck, P.A., 1989, Characterization of highly branched isoprenoid thiophenes occurring in sediments and immature crude oils: Organic Geochemistry, 14, 555-567.

Teske, A., Hinrichs, K.-U., Edgcoms, V., de Vera Gomez, A., Kysela, D., Sylva, S.P., Sogin, M.L., Jannasch, H.W., 2002, Microbial diversity in hydrothermal sediments in the Guaymas Basin: Evidence for anaerobic methanotrophic communities: Applied Environmental Microbiology, 68, 1994-2007.

Teske, A., Callaghan, A.V., LaRowe, D.E., 2014, Biosphere frontiers of subsurface life in the sedimented hydrothermal system of Guaymas Basin: Frontiers in Microbiology, 5, 362 .

Teske, A., Beer, D. de, McKay, L.J., Tivey, M.K., Biddle, J.F., Hoer, D., Lloyd, K.G., Lever, M.A., Røy H., Albert, D.B., Mendlovitz, H.P., MacGregor, B.J., 2016, The Guaymas Basin hiking guide to hydrothermal mounds, chimneys, and microbial mats: complex seafloor expressions of subsurface hydrothermal circulation: Frontiers in Microbiology, 7, 75, https://doi. org/10.3389/fmicb.2016.00075.

Thomson, I.D., Brassell, S.C., Eglinton, G., Maxwell, J.R., 1982, Preliminary analysis of section 481-2-2, in Curray, J.R., Moore, D.G., et al. (eds.), Initial Reports of the Deep Sea Drilling Project, Vol. 64: Washington, D.C., U.S. Government, Printing Office, 913-919.

Volkman, J.K., 1986, A review of sterol markers for marine and terrigenous organic matter: Organic Geochemistry, 9, 83-99.

Volkman, J.K., Barrett, S.M., Dunstan, G.A., Jeffrey, S.W., 1993, Geochemical significance of the occurrence of dinosterol and other 4-methyl sterols in a marine diatom: Organic Geochemistry, 20, 7-15.

Volkman, J.K., Barrett, S.M., Blackburn, S.I., Mansour, M.P., Sikes, E.L., Gelin, F., 1998, Microbial biomarkers: A review of recent research developments: Organic Geochemistry, 29, 1163-1179.

Whelan, J.K., Hunt, J.M., 1982, $C_{1}-C_{8}$ in Leg 64 sediments, Gulf of California, in Curray, J.R., Moore, D.G. et al. (eds.), Initial Reports of the Deep Sea Drilling Project, Vol. 64: Washington, D.C., U.S. Government Printing Office, 763-779.

Whelan, J.K., Simoneit, B.R.T., Tarafa, M., 1988, $\mathrm{C}_{1}-\mathrm{C}_{8}$ hydrocarbons in sediments from Guaymas Basin, Gulf of California - comparison to Peru Margin, Japan Trench and California Borderlands: Organic Geochemistry, 12, 171-194.

Williams, D., Becker, K., Lawver, L.A., von Herzen, R.P., 1979, Heat flow at the spreading centers of the Guaymas Basin, Gulf of California: Journal of Geophysical Research, 84, 6757-6769.

Manuscript received: october 26, 2018

Corrected manuscript received: february 2, 2019

Manuscript accepted: february 4, 2019 